\title{
ZNACZENIE I FORMY KSZTALTOWANIA KOMPETENCJI MENEDŻERSKICH KADRY KIEROWNICZEJ W MAŁYCH I ŚREDNICH PRZEDSIĘBIORSTWACH
}

DOI: 10.33141/po.2019.11.07

\section{Stefan Lachiewicz}

\section{Wprowadzenie}

$\mathbf{Z}$ agadnienie kształtowania i rozwoju kompetencji polskich menedżerów należy do ważniejszych obszarów rozważań w sferze nauki i praktyki zarządzania w ostatnich latach. Wynika to z założenia, że znaczące zmiany w gospodarce nie mogą dokonać się bez profesjonalnej i nowocześnie myślącej kadry kierowniczej, zwłaszcza w sektorze małych i średnich przedsiębiorstw. Sektor ten bowiem był tworzony w dużym stopniu od nowa w procesie transformacji gospodarki polskiej po 1989 roku. W zbiorowości właścicieli oraz menedżerów firm występowały wówczas szczególnie duże niedostatki kadrowe, a przede wszystkim kompetencyjne.

Celem artykułu jest identyfikacja i ocena roli oraz form kształtowania kompetencji menedżerskich kadry kierowniczej w małych i średnich przedsiębiorstwach.

Opracowanie składa się z trzech zasadniczych części. W pierwszej na podstawie analizy literatury przedmiotu przedstawiono znaczenie, elementy i możliwości budowania oraz doskonalenia kompetencji menedżerskich. Szczególną uwagę zwrócono na wybrane modele oraz formy kształtowania tych kompetencji, rozumiane jako sposoby i metody ich rozwoju. Część druga zawiera wyniki wybranych, w tym własnych autora artykułu, badań empirycznych na temat zakresu i form rozwoju kompetencji menedżerów z sektora małych i średnich przedsiębiorstw w Polsce. Znaczny jej fragment stanowią wyniki badań ankietowych, w których uczestniczył autor artykułu. Wybór prezentowanych badań wynikał z założenia, by przyjęte w nich problemy badawcze były ukierunkowane na ocenę kompetencji menedżerów w firmach $\mathrm{z}$ sektora MSP.

W podsumowaniu zaprezentowano podstawowe wnioski dotyczące kształtowania kompetencji menedżerskich właścicieli i kierowników w sektorze małych i średnich przedsiębiorstw.

\section{Kompetencje menedżerskie i formy ich ksztattowania}

A naliza wyników badań i opracowań z zakresu zarządzania zasobami ludzkimi wskazuje na potrzebę racjonalnego kształtowania kompetencji menedżerskich, a $\mathrm{z}$ drugiej strony podkreśla się, że jest to bardzo trudny proces z uwagi na dużą różnorodność elementów zaliczanych do tej kategorii, często o niewymiernym charakterze.

W oparciu o przegląd wypowiedzi licznych autorów A. Rakowska (2007, s. 46-55) stwierdza, że kompetencje dotyczą wykorzystania kwalifikacji i zdolności do działania, są uwarunkowane indywidualną wiedzą, umiejętnościami, motywami, charakterystykami osobistymi oraz wartościami. Szczególne znaczenie posiadają przy tym zdolności oraz wartości i postawy.

W swoich opracowaniach M. Armstrong przyjął rozumienie kompetencji jako potencjału przyczyniającego się do osiągnięcia określonych wyników. Stwierdza on, że to właśnie kompetencje pozwalają na odróżnienie menedżerów, którzy odnoszą sukcesy, od takich, których działania kończą się powodzeniem na niższym poziomie (Armstrong, 2000, s. 241). Z kolei T. Czapla i M. Malarski (2011, s. 273-274) stworzyli następującą listę specyficznych cech kompetencji:

- obserwowalność, czyli powiązanie zakresu treściowego

kompetencji z realizowanymi zadaniami;

- rozwijalność to podleganie rozwojowi poprzez procesy kształcenia, rozwijania i doskonalenia;

- stopniowalność to możliwość pomiaru poziomu kompetencji;

- rozłączność, oznaczającą, że poszczególne umiejętności składowe powinny być przypisane do jednej kompetencji, z którą logicznie posiadają najwięcej elementów wspólnych.

M. Morawski (2017, s. 57-59), analizując kategorię pracowników wiedzy na podstawie obszernych studiów literatury (np. Abbasi i in., 2009, s. 367-370), przypisuje im następujące cechy:

- wysokie kompetencje specjalistyczne, a także unikatową wiedzę i doświadczenie;

- wszechstronne umiejętności twórczego myślenia, interpersonalne i przywódcze, wynikające $\mathrm{z}$ wysokiego potencjału intelektualnego i dużej aktywności zawodowej;

- operowanie wiedzą w różnych jej procesach - od pozyskiwania, kreowania przez dzielenie się do wykorzystywania w zadaniach;

- zaangażowanie, na różnych poziomach organizacyjnych, w tworzenie nowej wiedzy, będącej podstawą procesu i rozwiązań innowacyjnych;

- dysponowanie wiedzą „cichą”, dającą możliwość tworzenia wartości dodatkowej w organizacji.

Szczególnie dużo miejsca poświęca się w ostatnim okresie tzw. kompetencjom miękkim (Penc, 2007, s. 153 i dalsze; Whiddett, Hollyforde, 2003, s. 56 i dalsze). Zalicza się do nich $\mathrm{z}$ reguły m.in. takie umiejętności i zdolności, jak: tworzenie dobrych relacji z podwładnymi, opartych na wzajemnym szacunku, umiejętności komunikacyjne, czyli sprawne prze- 
kazywanie informacji oraz odbiór informacji od współpracowników i otwartość na nowe idee.

W wielu opracowaniach zwraca się także uwagę na tzw. model Wielkiej Piątki, który wyróżnia (Robbins, 2001, s. 46) takie cechy, jak:

- ekstrawersja: towarzyskość, rozmowność, asertywność;

- ugodowość: życzliwość, gotowość do współpracy, ufność;

- sumienność: odpowiedzialność, niezawodność, wytrzymałość, dążenie do osiągnięć;

- stabilność emocjonalna: opanowanie, zapał, poczucie bezpieczeństwa w opozycji do napięcia, nerwowości, przygnębienia i niepewności;

- otwartość na doświadczenie: wyobraźnia, zmysł artystyczny, intelekt.

Interesujące jest również spojrzenie na listę kompetencji menedżerskich $\mathrm{z}$ punktu widzenia ról pełnionych w przedsiębiorstwie. W takim ujęciu zaprezentowanym przez J. Niemczyka (2010, s. 149), który połączył kompetencje i role decyzyjne menedżerów, zwraca się uwagę na:

- kompetencje przedsiębiorczego innowatora;

- umiejętności i kompetencje związane z rozmieszczeniem zasobów;

- wiedzę i umiejętności negocjacyjne;

- umiejętności rozwiązywania konfliktów.

Wydaje się, że jest to podejście odpowiadające także w dużym stopniu wymogom stanowisk menedżerów w małych i średnich przedsiębiorstwach. Ich praca charakteryzuje się $\mathrm{z}$ reguły połączeniem roli właściciela firmy i dyrektora lub prezesa spółki oraz cechuje się koniecznością pełnienia funkcji przedsiębiorcy i dysponenta zasobów, a także wiąże się $\mathrm{z}$ negocjacjami $\mathrm{z}$ dostawcami i klientami oraz $\mathrm{z}$ rozwiązywaniem różnorodnych sytuacji konfliktowych czy kryzysowych. Brak odrębnych stanowisk ds. promocji i kontaktów z otoczeniem rynkowym czy też do spraw kadrowych wymusza w warunkach firm $\mathrm{z}$ sektora MSP konieczność takiego szerokiego spojrzenia na kompetencje menedżerskie.

Obszerny zakres kompetencji menedżerskich i duże ich zróżnicowanie powodują, że zarówno w opracowaniach, jak i w działaniach praktycznych unika się tworzenia kompletnych zestawień tych kompetencji. Większą uwagę zwraca się natomiast na problem odpowiedniego ich kształtowania.

W oparciu o takie założenia powstało w ostatnich latach wiele koncepcji i modeli kształtowania kompetencji menedżerskich, związanych przede wszystkim z teorią organizacji uczącej się czy zarządzania wiedzą. I tak na przykład P. Senge (1998, s. 18-21) zwraca uwagę na następujące cechy organizacji uczącej się, które można w dużym stopniu odnieść do form kształtowania kompetencji menedżerskich:

- zespołowe uczenie się, czyli wspólne poszukiwanie nowych rozwiązań, doskonalenie komunikacji w zespołach oraz umiejętne zarządzanie wiedzą tworzoną wewnątrz organizacji;

- indywidualne mistrzostwo, czyli indywidualny rozwój poprzez ciągłe wyjaśnienia i pogłębianie osobistej wiedzy oraz dążenie do ustawicznego doskonalenia się;

- modele myślowe, rozumiane jako odkrywanie i odpowiednie kształtowanie własnych modeli myślowych (przekonania, wartości), służących realizacji wspólnej wizji;

- wspólna wizja, rozumiana jako łącząca personel firmy koncepcja przyszłości i rozwoju całej organizacji, z którą wszyscy identyfikują się, która inspiruje, motywuje i wyzwala zaangażowanie wszystkich pracowników;

- myślenie systemowe, czyli postrzeganie organizacji, w której się funkcjonuje, jako określonej całości, a siebie jako jej elementu.

Duże znaczenie przypisuje się także podejściu procesowemu w kształtowaniu i doskonaleniu kompetencji menedżerskich, które w języku koncepcji zarządzania wiedzą winno być oparte na określonych fundamentach typu konfrontacja i uzgadnianie wiedzy, poszerzanie wiedzy, kodyfikacja i wymiana wiedzy (Kowalczyk, Nogalski, 2007, s. 53-54; Perechuda, 2005, s. 121 i dalsze).

Modele kształtowania kompetencji menedżerskich wynikające $\mathrm{z}$ tych koncepcji stanowią więc określone układy działań prowadzących do doskonalenia i wzrostu takich kompetencji. Jeden $\mathrm{z}$ nich wyodrębnia następujące etapy (Rakowska, 2007, s. 145-147):

- symultaniczna ocena poziomu posiadanych kompetencji menedżerskich i poziomu kompetencji organizacyjnych;

- określenie posiadanych kompetencji organizacji i identyfikacja kompetencji organizacyjnych;

- określenie pożądanych kompetencji menedżerskich przez organizację;

- określenie luk kompetencji menedżerskich;

- działania związane z niwelowaniem luki w obszarze kompetencji organizacyjnych;

- działania związane $\mathrm{z}$ niwelowaniem luki kompetencji menedżerskich;

- realizacja i ocena działań związanych z niwelowaniem luki kompetencji menedżerskich.

Wspomniany już wyżej M. Armstrong (2000, s. 479) używa określenia zintegrowana metoda rozwoju kadry kierowniczej, która polega na uświadomieniu menedżerom tego, jakich kompetencji wymaga wykonywana przez nich praca, oraz tego, jakie kompetencje będą im niezbędne w przyszłości, w dalszej karierze zawodowej. Autor ten zwraca przy tym uwagę na to, że należy koncentrować się na ograniczonej liczbie podstawowych kompetencji, które powinny umożliwiać określonej organizacji rozwój i realizację planów strategicznych. Zalicza do nich przede wszystkim:

- umiejętności strategiczne, dotyczące zwłaszcza możliwości rozwoju rynku i produktu;

- umiejętności zarządzania zmianą, związane z planowaniem i realizacją zmian oraz przekonywaniem podwładnych do potrzeby zmian;

- umiejętności zarządzania zespołem pracowniczym;

- umiejętności zarządzania relacjami, a przede wszystkim dzielenia się informacjami i innymi zasobami;

- umiejętności zarządzania międzynarodowego, czyli pracy $\mathrm{z}$ ludźmi $\mathrm{z}$ różnych narodowości i kultur.

Te dwa wymienione wyżej podejścia zawierają wiele elementów wspólnych, zwłaszcza jeżeli chodzi o zwrócenie uwagi na potrzebę identyfikacji stanu kompetencji aktualnych oraz luki kompetencyjnej w odniesieniu do obecnego i przyszłych etapów rozwoju zawodowego menedżerów.

Na duże znaczenie kompetencji kadry przedsiębiorców i menedżerów $\mathrm{w}$ małych $\mathrm{i}$ średnich przedsiębiorstwach wskazują także badania prowadzone w innych krajach. I tak na przykład badacze analizujący sektor małych i średnich przedsiębiorstw usługowych w Malezji stwierdzili, że suk- 
cesy biznesowe badanych firm wynikają w dużym stopniu z wysokich kompetencji operacyjnych kadry kierowniczej, umiejętności uzyskiwania odpowiedniego udziału w rynku, odpowiadającego wielkości i możliwościom gospodarczym przedsiębiorstw oraz umiejętności oferowania wyspecjalizowanych usług (Yahya i in., 2011, s. 10410-10418). Natomiast K.Ch. Agbim (2013, s. 8-16) badający zbliżone relacje w sektorze handlowym w Nigerii wskazuje na następujące umiejętności menedżerskie, zapewniające sukces biznesowy dla małych i średnich przedsiębiorstw:

- umiejętność planowania i budżetowania strategii marketingowej, zapewniającej atrakcyjny asortyment produkcji;

- umiejętność szybkiego reagowania na zmiany w otoczeniu rynkowym;

- umiejętność oceny problemów sprzedażowych i utrzymania dobrych relacji z klientami;

- umiejętność koncentrowania się na jakości produktu w celu zdobycia znacznego udziału w rynku;

- umiejętność zarządzania wiedzą w celu pozyskania i utrzymania kompetentnych pracowników.

Analizując problematykę rozwoju zawodowego pracowników w aspekcie szkoleń i uczenia się, J. Szaban (2011, s. 306-307) wskazuje na dużą przydatność tzw. modelu uświadomionej kompetencji. Zawiera on rozwinięcie wcześniejszych koncepcji (Gordon, 2010) i wyodrębnia następujące etapy:

- nieuświadomionej niekompetencji, kiedy pracownik nie zdaje sobie sprawy ze swoich braków i z tego, że powinien się uczyć oraz rozwijać;

- uświadomionej niekompetencji, kiedy to dochodzi do uświadomienia obszarów braków w sferze kompetencji zawodowych;

- uświadomionej kompetencji, która obejmuje zespół działań szkoleniowych prowadzących do nabycia kompetencji i świadomości o ich posiadaniu;

- nieuświadomionej kompetencji, gdy uczący się jest na tyle biegły, że często nie zdaje sobie sprawy ze swoich kompetencji i z tego, że może już uczyć innych.

J. Szaban (2011) wskazuje jeszcze na możliwość wystąpienia piątego etapu, tzw. metauświadomionej kompetencji, podczas którego człowiek jest świadomy tego, jakimi kompetencjami się posługuje oraz jest w stanie analizować, adaptować i zwiększać swoją aktywność.

$\mathrm{Na}$ zakończenie analizy różnorodnych modeli rozwoju kompetencji menedżerskich zostanie przedstawiona propozycja A. Suchodolskiego (2008, s. 138 i dalsze). Jest to opis faz procesu zarządzania zasobami ludzkimi, który został zbudowany na użytek obszernych badań empirycznych prowadzonych w Katedrze Zarządzania Kadrami Uniwersytetu Ekonomicznego we Wrocławiu. Wyodrębniono w nim następujące fazy:

- Preparacja rozwoju pracowników, w tym m.in.:

" diagnozowanie potencjału rozwojowego pracowników;

» analizowanie planów rozwoju organizacji i warunków otoczenia;

» konstruowanie planu ścieżki kariery zawodowej;

" tworzenie programu przedsięwzięć szkoleniowych;

- Realizacja procesu rozwoju pracowników, w tym:

» umożliwienie pracownikom zaspokojenia potrzeb samorealizacji w miejscu pracy;

» doskonalenie kwalifikacji pracowników;

» przemieszczanie pracowników;
- Kontrola procesu rozwoju pracowników, w tym:

» ocenianie zachowań i efektów pracy;

" monitorowanie postępów w rozwoju pracowników;

» korygowanie planów rozwoju pracowników i działań rozwojowych.

Należy przy tym zwrócić uwagę na to, że plan rozwoju kompetencji kierowniczych zależy także w dużym stopniu od przyjętego modelu kariery zawodowej na stanowiskach menedżerskich.

Z powyższej analizy wynika, że cały ciąg działań rozwojowych powinien prowadzić do istotnego rozwoju kompetencji menedżerskich. Ważne znaczenie pełni też dobór odpowiednich metod rozwoju pracowników, stosowanych w ramach poszczególnych etapów. W licznych opracowaniach z zakresu zarządzania zasobami ludzkimi oraz w praktyce działania ośrodków szkoleniowych, uczelni, firm doradczych i korporacji zaleca się wiele różnych metod. Zalicza się do nich między innymi: mentoring i coaching, szkolenia menedżerskie, e-learning, treningi wrażliwości i techniki relaksacyjne, doskonalenie $\mathrm{w}$ ramach ośrodków rozwoju kompetencji w dużych przedsiębiorstwach i inne rozwiązania.

\section{Kierunki rozwoju kompetencji menedżerów z sektora MSP w świetle wybranych badań empirycznych}

D rzeprowadzone w 2004 roku badania pilotażowe w grupie 65 uczestników szkoleń i studiów podyplomowych, zatrudnionych na stanowiskach średniego i wyższego szczebla zarządzania, głównie w organizacjach gospodarczych małej i średniej wielkości na terenie województw Polski Centralnej (łódzkie, mazowieckie i świętokrzyskie) wykazały, że odczuwali oni liczne braki kompetencyjne w momencie obejmowania stanowiska kierowniczego. Braki te dotyczyły przede wszystkim (Lachiewicz, 2007, s. 255-256):

- podejmowania decyzji $\mathrm{w}$ bezpośrednim operacyjnym działaniu (44,6\% wskazań),

- sfery motywowania pracowników (29,2\%);

- wiedzy i umiejętności w zakresie negocjacji z kontrahentami zewnętrznymi i wewnątrz firmy $(15,4 \%)$;

- trudności w budowaniu planów i strategii przedsiębiorstwa oraz w innych obszarach zarządzania, np. w prowadzeniu kontroli jakości (10,8\% wskazań).

Wydatki na szkolenia i liczebność menedżerów oraz innych pracowników w nich uczestniczących są zależne od sytuacji ekonomicznej przedsiębiorstw i od koniunktury w skali całej gospodarki czy jej poszczególnych regionów. I tak na przykład A. Pocztowski (2010) wskazuje na to, że spowolnienie gospodarcze, jakie wystąpiło także w Polsce pod koniec pierwszej dekady XXI wieku, spowodowało liczne skutki dla zakresu działań szkoleniowych w przedsiębiorstwach.

Do podstawowych skutków wpływu kryzysu na zmianę polityki i praktyki personalnej stwierdzonych na podstawie przeprowadzonych badań A. Pocztowski (2010, s. 265) zalicza:

- blokadę przyjęć nowych pracowników (48\% wskazań);

- ograniczenie wydatków na szkolenia (39\%);

- zmniejszenie poziomu wynagrodzeń (17\%);

- ograniczenie dodatkowych świadczeń pracowniczych (15\%);

- zmniejszenie budżetów działów personalnych (17\% wskazań). 
W analizach procesów szkolenia i doskonalenia personelu w polskich organizacjach gospodarczych pojawiają się także wątki krytyczne. I tak na przykład stwierdza się, że polskie przedsiębiorstwa $\mathrm{z}$ reguły zdają sobie sprawę z możliwości wzrostu efektywności i konkurencyjności poprzez dokształcanie i doskonalenie pracowników, ale świadomości tej nie zawsze towarzyszą konkretne decyzje i wydatki na szkolenia. Często też wskazuje się, że proces doskonalenia kadry kierowniczej w wielu przypadkach nie pozwala na osiągnięcie zakładanych korzyści i rzeczywistych zmian w sferze kompetencji. Stąd też w opracowaniach z zakresu tej problematyki zwraca się uwagę na potrzebę pomiaru wyników szkoleń i innych form doskonalenia personelu (np. za pomocą modelu oceny efektywności szkoleń D.L. Kirkpatricka) oraz na inne przedsięwzięcia usprawniające działania szkoleniowe. Można tutaj wymienić kompleksową analizę potrzeb szkoleniowych kadry menedżerskiej oraz zespołu sukcesorów w przedsiębiorstwach, przekształcenia w zakresie tematyki szkoleń i metod ich prowadzenia oraz bardziej skuteczną ocenę zmian w efektach pracy, postawach i umiejętnościach uczestników szkoleń po upływie określonego czasu od ich zakończenia.

Ważność problemów kształtowania kompetencji menedżerskich dostrzeżono także $\mathrm{w}$ trakcie obszernych badań nad przedsiębiorczością technologiczną w sektorze małych i średnich przedsiębiorstw. Badania te zostały przeprowadzone w latach 2012-2013 z pomocą metody ankiety kwestionariuszowej przez pracowników Katedry Zarządzania Politechniki Łódzkiej ${ }^{1}$ w grupie 300 przedsiębiorstw z Polski Centralnej (głównie z województwa łódzkiego).

W badaniach zastosowano losowy dobór próby na podstawie operatu populacji, którym był wykaz podmiotów gospodarczych udostępnionych przez zewnętrzną firmę badań społecznych, z którą zespół badawczy współpracował w trakcie badań empirycznych. W operacie znalazły się celowo dobrane firmy spełniające następujące warunki:

- odpowiednia wielkość firmy mierzona liczbą zatrudnionych pracowników;

- siedziba firmy (głównie teren woj. łódzkiego);

- określony rodzaj sektorów i branż działalności gospodarczej.

W tabeli 1 przedstawiono strukturę badanych przedsiębiorstw.

Głównym celem tych badań było ustalenie zakresu oraz uwarunkowań i barier wdrażania rozwiązań z zakresu przedsiębiorczości technologicznej w badanej grupie firm. Jako jedno $\mathrm{z}$ ważnych uwarunkowań przyjęto podczas badań kompetencje kadry kierowniczej tych przedsiębiorstw i skłonność do ich rozwoju poprzez szkolenia i doskonalenie umiejętności.

W 66\% przypadków byli to właściciele przedsiębiorstw, a pozostałą grupę (103 osoby) stanowili menedżerowie kontraktowi. Poza tym $31 \%$ badanych było w wieku $31-40$ lat, a 29\% w wieku 41-50 lat. Z kolei 55\% posiadało wykształcenie wyższe, $41 \%$ wykształcenie średnie i $4 \%$ zasadnicze zawodowe. Jeżeli chodzi o kierunek wykształcenia, to 58\% osób dysponowało wykształceniem technicznym, 31\% ekonomicznym, a w pozostałej grupie (11\%) występowali prawnicy, lekarze, filolodzy, psychologowie i przedstawiciele innych kierunków.

$\mathrm{Na}$ podstawie tej analizy oraz odpowiedzi udzielanych na inne pytania można stwierdzić, że w ostatnich dziesię- cioleciach obserwuje się znaczący napływ młodych i lepiej wykształconych ludzi do firm z sektora MSP. Wpływa to pozytywnie na ogólny poziom kompetencji kadry menedżerskiej w tych przedsiębiorstwach, a także tworzy podstawy do wzrostu poziomu innowacyjności oraz efektywności w ich funkcjonowaniu.

$\mathrm{W}$ wypowiedziach respondentów podkreślono to, iż $\mathrm{z}$ reguły w sektorze MSP własne aktywa kompetencyjne (wiedza, kapitał intelektualny) są niewystarczające i istotne są także odpowiednie kompetencje w zakresie transferu wiedzy z otoczenia tych firm. Badane przedsiębiorstwa wykorzystują jednak w tym procesie przede wszystkim znane źródła wiedzy zewnętrznej: Internet, przekaz klientów i pracowników, media społecznościowe (Flaszewska i in., 2013, s. 146).

Natomiast takie źródła wiedzy jak uczelnie wyższe czy jednostki naukowo badawcze są wykorzystywane w znacznie mniejszym stopniu.

Z punktu widzenia tematyki tego opracowania istotne jest również nastawienie osób badanych do rozwoju kompetencji kadry menedżerskiej poprzez szkolenia, kursy i inne formy doskonalenia zawodowego. I tutaj należy stwierdzić, że wiedza na temat organizacji szkoleniowych i ich oferty plasuje się w ocenach badanych na poziomie średnim. Posiadają oni znacznie więcej informacji na temat możliwości otrzymania zasobów wspierających firmę z banków, instytucji leasingowych i ubezpieczeniowych (tzw. twarde zasoby) niż z ośrodków szkoleniowo-doradczych i informacyjnych oraz uczelni wyższych czy izb gospodarczych. Około 40\% respondentów wskazało, że brakuje im wiedzy na ten temat.

Podane wyżej i inne odpowiedzi respondentów na pytania kwestionariusza ankiety wskazują na większe zainteresowanie kadry kierowniczej w sektorze MSP szkoleniami z zakresu zagadnień ekonomiczno-finansowych, prawnych, podatkowych i inwestycyjnych. W mniejszym stopniu natomiast widoczna jest motywacja do szkolenia się w zakresie tzw. miękkich problemów zarządzania, chociaż i tutaj widoczne są pewne korzystne zmiany w stosunku do lat wcześniejszych.

Na pozytywne tendencje w zakresie wykształcenia kadry pracowniczej małych i średnich przedsiębiorstw wskazuje także M. Zastempowski (2019) w badaniach późniejszych. Badania te dotyczyły innowacyjności małych przedsiębiorstw i objęły 202 firmy z tej kategorii zlokalizowanych w województwach: mazowieckim, śląskim i wielkopolskim. Dane dotyczące ogółu pracowników (nie tylko kadry kierowniczej) wskazują, że blisko 33\% zatrudnionych posiadało wykształcenie wyższe, 38,5\% średnie, $25 \%$ zasadnicze zawodowe, a jedynie 2,3\% pracowników tych firm legitymowało się wykształceniem podstawowym i gimnazjalnym (Zastempowski, 2019, s. 122). Biorąc pod uwagę to, że z reguły poziom wykształcenia kadry kierowniczej jest wyższy od poziomu średniego dla ogółu pracowników, można uznać, że badania te potwierdzają pozytywne trendy w zakresie kompetencji menedżerskich, mierzonych poziomem wykształcenia.

Do podobnych wniosków prowadzą także wyniki badań przeprowadzonych przez M. Świeszczak (2016, s. 193), które dotyczyły potencjału innowacyjnego firm z sektora małych i średnich przedsiębiorstw województwa łódzkiego. Objęły one 100 przedsiębiorstw z sektora MSP i były przeprowadzone 
Tabela 1. Struktura badanych przedsiębiorstw według formy prawnej, wieku i obszaru dziatania

\begin{tabular}{|l|c|c|c|c|c|l|c|c|}
\hline \multicolumn{1}{|c|}{ Forma prawna } & Liczba & $\%$ & Wiek firmy & Liczba & $\%$ & Obszar działania & Liczba & $\%$ \\
\hline Osoba fizyczna & 179 & 59 & Do 3 lat & 5 & 2 & Lokalny & 105 & 35 \\
\hline Spółka cywilna & 34 & 11 & $4-5$ lat & 30 & 10 & Regionalny & 79 & 27 \\
\hline Spółka handlowa & 79 & 27 & $6-10$ lat & 90 & 30 & Krajowy & 67 & 22 \\
\hline Inne formy & 8 & 3 & Powyżej 10 lat & 173 & 58 & Międzynarodowy & 49 & 16 \\
\hline
\end{tabular}

Źródto: opracowanie własne

za pomocą ankiety kwestionariuszowej CAWI. Z badań tych wynika, że na potencjał innowacyjny tych przedsiębiorstw wpływają w dużym stopniu kompetencje kadry kierowniczej. I tak na przykład $72 \%$ badanych oceniło wiedzę, doświadczenie i umiejętności osoby zarządzającej przedsiębiorstwem jako zdecydowanie pozytywne dla rozwoju potencjału innowacyjnego badanych przedsiębiorstw. Wysoką range przypisano także skłonności pracowników do podnoszenia kwalifikacji (54\% wskazań na wariant wpływ pozytywny) i kreatywności pracowników (44\% wskazań na ten wariant).

Powyższe wyniki badań wskazują więc na występowanie korzystnych tendencji w zakresie kształtowania kompetencji menedżerskich kadry kierowniczej w małych i średnich przedsiębiorstwach w Polsce. Dotyczą one wzrostu zainteresowania szkoleniami i doskonaleniem kompetencji w środowisku tej kadry, rozwoju programów i ofert szkoleniowych ze strony uczelni, ośrodków szkoleniowych, fundacji i innych instytucji oraz napływu młodych lepiej wykształconych menedżerów do polskich małych i średnich przedsiębiorstw. Należy też wskazać na potrzebę określonych korekt w odniesieniu do zakresu i form tych działań.

\section{Podsumowanie}

$\mathbf{P}$ rzedstawione w tym opracowaniu wyniki studiów literaturowych oraz wybranych badań empirycznych w ostatnich latach wskazują na znaczący wzrost roli kompetencji menedżerskich $\mathrm{w}$ grupie przedsiębiorców i kierowników przedsiębiorstw z sektora MSP,. Funkcjonujące w literaturze oraz $\mathrm{w}$ świadomości środowisk menedżerskich koncepcje i modele kształtowania kompetencji kierowniczych pokazują różne praktyczne formy ich rozwoju. Wykorzystują one specyficzne formy diagnozowania kompetencji, zespołowego uczenia się, indywidualnego rozwoju, wykorzystania coachingu, mentoringu i e-learningu oraz monitorowania i korygowania rozwoju menedżerów.

Implementacja znaczącej wiedzy związanej z kształtowaniem kompetencji menedżerskich jest szczególnie ważna $\mathrm{w}$ odniesieniu do kadry kierowniczej z sektora małych i średnich przedsiębiorstw. Wieloletnie zaniedbania związane $\mathrm{z}$ niedocenianiem roli małych firm w gospodarce polskiej, słaby napływ profesjonalnej kadry kierowniczej do tych przedsiębiorstw w pierwszym okresie po 1989 roku oraz znacznie mniejsze środki przeznaczone na cele szkoleniowo-rozwojowe w stosunku do dużych organizacji gospodarczych to główne przyczyny wolniejszego tempa zmian w tej sferze.

Przedstawione w artykule wyniki badań pokazują jednak, że w ostatnim okresie zachodzą także w tym sektorze korzystne zmiany. Dotyczą one następujących kierunków:
- wzrost zainteresowania szkoleniami i innymi formami doskonalenia zawodowego ze strony przedsiębiorców i menedżerów z sektora małych i średnich przedsiębiorstw;

- duża rola programów szkoleniowych finansowanych z funduszy Unii Europejskiej w kształtowaniu kompetencji menedżerów $\mathrm{z}$ sektora MSP;

- coraz większe zaangażowanie ośrodków szkoleniowych, uczelni i innych instytucji (np. PARP, izby gospodarcze, inkubatory przedsiębiorczości) $\mathrm{w}$ proces przygotowania i realizacji działań rozwijających poziom kompetencji kadry kierowniczej;

- dotychczasowe większe ukierunkowanie przedsiębiorców i menedżerów $\mathrm{z}$ małych i średnich przedsiębiorstw na rozwijanie tzw. kompetencji twardych jest stopniowo równoważone nabywaniem kompetencji miękkich (np. z zakresu komunikacji, motywowania i oceny pracowników);

- napływ młodych osób do zarządzania oraz znaczny rozwój dużej części małych i średnich przedsiębiorstw wpływają pozytywnie na ogólny poziom kompetencji kadry kierowniczej w tym sektorze, a zwłaszcza na wzrost poziomu wykształcenia oraz kreatywności i innowacyjności w procesie zarządzania.

Zdając sobie sprawę, że przeprowadzona w tym opracowaniu analiza posiada $\mathrm{z}$ wielu powodów charakter wycinkowy, należy wskazać na możliwe kierunki dalszych badań tej problematyki. Na szczególną uwagę zasługują badania dotyczące wpływu transferu kadry kierowniczej z sektora dużych przedsiębiorstw oraz z instytucji i urzędów administracyjnych na poziom kompetencji menedżerów z małych i średnich firm. Ważne byłyby także analizy przepływów kadrowych w odwrotnym kierunku i ich skutków dla potencjału menedżerskiego firm z sektora MSP oraz dotyczące dostosowania systemu szkolenia do specyfiki pracy kierowniczej w małych i średnich przedsiębiorstwach.

\section{prof. dr hab. Stefan Lachiewicz \\ Politechnika Łódzka \\ Wydział Zarządzania i Inżynierii Produkcji \\ ORCID: 0000-0003-1238-4585 \\ e-mail: stefan.lachiewicz@p.lodz.pl}

\section{Przypis}

1) Badania zrealizował zespół w składzie: S. Flaszewska, M. Kurowska, S. Lachiewicz (kierownik), M. Matejun, S. Mosińska, K. Szymańska i A. Walecka w ramach projektu badawczego finansowanego ze środków Narodowego Centrum Nauki w latach 2012-2013. 


\section{Bibliografia}

[1] Abbasi S.M., Belhadjali K.W., Hollman K.W. (2009), Managing Knowledge Workers for Sustaining Competitive Advantage, "Competition Forum”, Vol. 7(2), pp. 367-370.

[2] Agbim K.Ch. (2013), The Relative Contribution of Management Skills to Entrepreneurial Success: A Survey of Small and Medium Enterprises (SMEs) in the Trade Sector, ,Journal of Business and Management", Vol. 1, pp. 8-16.

[3] Armstrong M. (2000), Zarzadzanie zasobami ludzkimi, Oficyna Ekonomiczna, Dom Wydawniczy ABC, Kraków.

[4] Czapla T., Malarski M. (2011), Wykorzystanie zarzadzania kompetencjami $w$ systematyzacji narzędzi zarzadzania zasobami ludzkimi, [w:] M. Czerska, M. Gableta (red.), Przełomy $w$ zarzadzaniu. Zarządzanie zasobami ludzkimi, Towarzystwo Naukowe Organizacji i Kierownictwa „Dom Organizatora”, Toruń, s. 265-283.

[5] Flaszewska S., Mosińska S., Szymańska K., Walecka A. (2013), Czynniki rozwoju przedsiębiorczości technologicznej w badanych przedsiębiorstwach, [w:] S. Lachiewicz, M. Matejun, A. Walecka (red.), Przedsiębiorczość technologiczna w malych i średnich firmach. Czynniki rozwoju, Wydawnictwo WNT, Warszawa, s. 143-169.

[6] Gordon Th.T. (2010), Origins of the Gordon Model, Gordon Training International www.gordontraining.com.

[7] Kowalczyk A., Nogalski B. (2007), Zarzadzanie wiedzą. Koncepcja i narzędzia, Difin, Warszawa.

[8] Lachiewicz S. (2003), Rozwój sektora malych i średnich przedsiębiorstw w gospodarce polskiej, [w:] S. Lachiewicz (red.), Małe firmy w regionie łódzkim. Znaczenie - struktura - warunki działania, Wydawnictwo Politechniki Łódzkiej, Łódź, s. 49-65.

[9] Lachiewicz S. (2007), Menedżerowie w strukturach władzy organizacji gospodarczych, PWE, Warszawa.

[10] Lachiewicz S., Zakrzewska-Bielawska A. (2017), Studia podyplomowe jako forma doskonalenia kompetencji menedżerskich, „Zeszyty Naukowe Politechniki Łódzkiej, seria: Organizacja i Zarządzanie", Nr 68, s. 43-52.

[11] Morawski M. (2017), Pracownik kluczowy w procesie dzielenia się wiedzą. Motywy, warunki, metody, Wydawnictwo Uniwersytetu Ekonomicznego we Wrocławiu, Wrocław.

[12] Niemczyk J. (2010), Kompetencje i role decyzyjne, [w:] M. Morawski, J. Niemczyk, K. Perechuda, E. Stańczyk-Hugiet (red.), Zarzadzanie. Kanony i trendy, C.H. Beck, Warszawa, s. 147-158.

[13] Penc J. (2007), Nowoczesne kierowanie ludźmi, Difin, Warszawa.

[14] Perechuda K. (2005), Procesy kreowania wiedzy $w$ organizacjach sieciowych, [w:] K. Perechuda (red.), Zarzadzanie wiedza w przedsiębiorstwie, Wydawnictwo Naukowe PWN, Warszawa, s. 121-126.

[15] Pocztowski A. (2010), Zarzadzanie zasobami ludzkimi wobec dotychczasowych doświadczeń i przyszłych wyzwań, [w:] S. Lachiewicz, B. Nogalski (red.), Osiagnięcia i perspektywy nauk o zarządzaniu, Oficyna a Wolters Kluwer business, Warszawa, s. 256-273.
[16] Rakowska A. (2007), Kompetencje menedżerskie kadry kierowniczej we wspólczesnych organizacjach, Wydawnictwo Uniwersytetu Marii Curie Skłodowskiej, Lublin.

[17] Raport o stanie małych iśrednich przedsiębiorstw w Polsce $w$ latach 1998-1999 (2000), Polska Fundacja Promocji i Rozwoju Małych i Średnich Przedsiębiorstw, Warszawa.

[18] Robbins S.P. (2001), Zasady zachowania $w$ organizacji, Zysk i S-ka, Poznań.

[19] Senge P. (1998), Piąta dyscyplina, Dom Wydawniczy ABC, Warszawa.

[20] Suchodolski A. (2008), Doskonalenie i rozwój kadry menedżerskiej, [w:] T. Listwan, M. Stor (red.), Zarzadzanie kadra menedżerska $w$ organizacjach międzynarodowych $w$ Polsce, Wydawnictwo Uniwersytetu Ekonomicznego we Wrocławiu, Wrocław, s. 136-158.

[21] Szaban J. (2011), Zarzadzanie zasobami ludzkimi w biznesie i w administracji publicznej, Difin, Warszawa.

[22] Świeszczak M. (2016), Potencjat innowacyjny firm z sektora małych $i$ średnich przedsiębiorstw. Przykład województwa łódzkiego, Wydawnictwo Uniwersytetu Łódzkiego, Łódź.

[23] Whiddet S., Hollyforde S. (2003), Modele kompetencyjne w zarządzaniu zasobami ludzkimi, Oficyna Ekonomiczna, Kraków.

[24] Yahya A.Z., Fatt Ch.K., Othman A.S., Rahman J.A., Moen J. (2011), Management Skills and Entrepreneurial Success of Small and Medium Enterprises (SMEs) in the Services Sector, „African Journal of Business Management”, Vol. 5(26), pp. 10410-10418.

[25] Zastempowski M. (2019), Innowacyjność małego przedsiębiorstwa, Wydawnictwo Naukowe Uniwersytetu Mikołaja Kopernika, Toruń.

\section{Role and Forms of Managerial Competences Development in Small and Medium Enterprises}

\section{Summary}

Management executives, who play a key role in the activities of any company, should attach a great importance to the development of managerial competences. This applies especially to small and medium-sized enterprises. Entrepreneurs and managers of these enterprises should have a wide range of competencies due to the limited number of positions for specialist and advisers. The aim of the study is to establish and evaluate the role and forms in developing managerial competences in small and medium-sized enterprises. The article presents basic concepts, models and forms of developing managerial competences based on literature studies and the results of selected empirical research in small and medium-sized enterprises

\section{Keywords}

managerial competences, small and medium-sized enterprises, forms of developing competences

\section{\begin{tabular}{l|l} 
Ministerstwo Nauki \\
i Szkolnictwa Wyższego
\end{tabular}}

Projekt digitalizacji publikacji naukowych czasopisma Przegląd Organizacji w celu zapewnienia i utrzymania otwartego dostępu do artykułów przez sieć Internet jest współfinansowany przez Ministerstwo Nauki i Szkolnictwa Wyższego w ramach działalności upowszechniania nauki - umowa nr 624/P-DUN/2018. 